\title{
Impact of behaviour and lifestyle on bladder health
}

Bladder conditions, including UTI, UI, and bladder cancer, are highly prevalent and affect a wide range of populations. There are a variety of modifiable behavioral and lifestyle factors that influence bladder health. Some factors, such as smoking and obesity, increase the risk or severity of bladder conditions, whereas other factors, such as pelvic floor muscle exercise, are protective. Although clinical practice may be assumed to be the most appropriate ground for education on behavioral and lifestyle factors that influence bladder health, it is also crucial to extend these messages into the general population through public health interventions to reach those who have not yet developed bladder conditions and to maximize the prevention impact of these behaviors. Appropriate changes in these factors have the potential for an enormous impact on bladder health if implemented on a population-based level.

\section{Introduction}

It is widely accepted that individual behaviour patterns, particularly diet and exercise, affect health status through impact on multiple systems. These relationships have been convincingly demonstrated in various disease states, including cardiovascular disease (e.g. myocardial infarction, stroke) and metabolic conditions (e.g. diabetes) $(1,2)$. However, less recognised is the relationship between behaviour and bladder health.

Similar to other disease states, some behavioural and lifestyle factors can precipitate or exacerbate bladder conditions, and as such represent bladder health risks, whereas other factors can contribute positively to bladder health by preventing or modifying existing bladder conditions $(3,4)$. Currently, some of the evidence supporting which specific factors represent a bladder health risk or whether they are modifiable is limited. However, awareness and implementation at a societal level of behavioural modifications that are established to prevent or reverse bladder disease/dysfunction may lead to a substantial reduction in the human and economic burdens of impaired bladder health, as well as an improvement in overall health.

In this article, we review the current state of knowledge on behavioural and lifestyle factors that influence bladder conditions, including the lower urinary tract symptoms (LUTS) of urinary incontinence (UI), urgency, frequency and nocturia, as well as urinary tract infection (UTI), bladder pain syndrome/interstitial cystitis (BPS/IC) and bladder cancer. Among the behavioural factors considered are cigarette smoking, dietary intake, body-mass index, fluid intake, voiding habits and techniques, bowel habits, physical activity and exercise, and pelvic floor muscle skills and exercise. In addition, we describe potential modifications of these behavioural and lifestyle factors that could reduce or ameliorate risk and optimise bladder health and also provide suggestions to incorporate behavioural modifications into public health programmes. Our goals are to increase awareness of the relationship between behaviour and bladder health, to stimulate changes in both public decision-making and individual habits, and to promote incorporation of behavioural modifications discussed here into public health programmes in an effort to improve both bladder health and overall health at a population-based level.

\section{Behavioural and lifestyle factors that influence bladder health}

\section{Cigarette smoking}

Cigarette smoking is directly correlated with the development of bladder cancer. Smokers have a threefold higher risk of bladder cancer, and the American Cancer Society reports that the incidence increases with advancing age (5). The duration of smoking appears to be particularly relevant $(6,7)$. In a population-based study of smoking practices and risk of bladder cancer, smoking fewer cigarettes over a long period of time was found to be more harmful than smoking more cigarettes over a shorter period of time (7). Gender may also be associated with bladder cancer incidence, as it has been demonstrated that the risk of bladder cancer among smokers is significantly higher in women compared with men who smoked a comparable amount of cigarettes over the same length of time (8). The exact causal

\section{Bladder \\ conditions are \\ highly \\ prevalent and \\ affect a wide \\ range of \\ populations. \\ Behavioral \\ modifications \\ can improve \\ bladder health \\ or prevent or \\ reduce the \\ deterioration \\ of bladder \\ health}


pathway between smoking and bladder cancer risk has not yet been established; however, various chemicals in cigarettes, such as nicotine, have known carcinogenic properties, and smoking is associated with abnormal growth of bladder lining cells (9).

Smoking cessation has been shown to decrease the risk of bladder cancer $(8,10)$. Thus, there is an ongoing need for educational initiatives to convey information explaining the need to quit smoking, as well as smoking cessation programmes to assist individuals, including those with or at increased risk for developing bladder cancer, to change their behaviour $(11,12)$. Health professionals have a critical role in disseminating information to populations they interact with regarding the risk of bladder cancer associated with smoking and in encouraging smoking cessation (12).

In addition to its link to bladder cancer, smoking has also been associated with increased risk of BPS/ IC and other LUTS, including UI, frequency, urgency, nocturia, incomplete emptying and hesitancy (13-25). In a cross-sectional study of women seeking gynaecological care, an association was found between bladder pain and current smoking; tobacco use was the only modifiable risk factor identified (22). In a case-control study of women with and without UI, it was demonstrated that previous and current cigarette smoking increased the odds of both stress UI and urgency UI (13). When modifiable lifestyle factors associated with UI were examined in a large, epidemiological study, heavy smoking (former or current) had one of the highest odds ratios (14).

A prospective cohort study comparing smokers and non-smokers determined that smokers had a stronger urethral sphincter, which may have a protective effect against stress UI. However, the authors concluded that violent coughing by smokers was likely to contribute to stress UI because of earlier development of anatomical and pressure transmission defects, leading to weakening of the sphincters (15). Whether the coughing is causally related to stress UI, exacerbates the condition, or contributes to earlier development has not yet been elucidated.

In a longitudinal study, smoking increased the 1year incidence of overactive bladder in women, but did not significantly affect the risk of stress UI (25). In men, smoking has been associated with both overactive bladder and prostatic enlargement $(17,18,23,24)$, although results have been inconsistent $(20,26)$. In a longitudinal study of men aged 40 70 years, cigarette smoking was associated with incident benign prostatic enlargement (23) and it was suggested that avoidance of smoking might be of benefit. A population-based cross-sectional study of men in Austria also showed a positive correlation between the International Prostate Symptom Score (used to assess benign prostatic enlargement symptomatology) and the daily nicotine usage of current smokers (24). In this study, the association with nicotine was shown for storage symptoms, but not for voiding symptoms associated with benign prostatic enlargement.

\section{Dietary intake}

Although nutrition-based interventions or activities have historically been focused on disease states such as cardiovascular and metabolic conditions, ample evidence suggests that it may be beneficial to incorporate the impact of dietary intake on bladder health.

\section{Caffeine}

Foods and beverages containing caffeine have been reported to be risk factors for urgency, frequency and UI. Caffeine promotes urgency and frequency through diuresis, decreased threshold of sensation at filling phase, and increased flow rate and voided volume $(27,28)$. The association of daily caffeine intake with UI is described in a prospective cohort study of 65,176 adult women (27). A significant association with weekly incontinence was reported for the group with the highest $(>450 \mathrm{mg} /$ day $)$ vs. the lowest $(<150 \mathrm{mg} /$ day) caffeine intake (RR 1.19, 95\% CI 1.06-1.34). Risk of UI associated with high caffeine intake was $25 \%$ (27).

\section{Alcohol}

Alcohol can promote urgency and frequency by interfering with the bladder signals regulating micturition. Alcohol also acts as a diuretic and causes dehydration (29). A study in men concluded that among other factors, alcohol consumption was an avoidable risk factor for the development of LUTS (30). Another study in men aged $\geq 20$ years demonstrated that high alcohol consumption was a factor positively associated with an increased risk of moderate and severe LUTS (31). However, studies are inconsistent, with some showing an inverse relationship between alcohol consumption and the incidence of overactive bladder (26) and benign prostatic enlargement $(23,32,33)$. A meta-analysis of 19 studies (120,091 men) demonstrated that alcohol reduced the risk of benign prostatic enlargement, but not LUTS (32). The causal pathways and exact mechanisms that are associated with this reduction in risk are still in an exploratory phase (32).

\section{Bladder irritants}

In addition to caffeine and alcohol, several foods and beverages have been identified as triggering or exacerbating urinary symptoms, particularly in patients with 
Table 1 Bladder- and prostate-friendly foods

\begin{tabular}{|c|c|c|c|}
\hline Beverages & $\begin{array}{l}\text { Chamomile tea, Evian, pear juice, } \\
\text { pure blueberry juice, } \\
\text { milk, peppermint tea, almond milk, } \\
\text { rice milk, Lactaid, } \\
\text { non-dairy creamer, non-alcoholic eggnog }\end{array}$ & $\begin{array}{l}\text { Alfalfa tea, bottled water, herbal coffees, } \\
\text { low-acid decaf coffee, roasted carob } \\
\text { tea or coffee, low-acid juices, gin, rice milk, } \\
\text { decaf root beer w/ice (not diet), rum, tap water, } \\
\text { vodka, some sports drinks }\end{array}$ & $\begin{array}{l}\text { Alcohol, carbonated water, } \\
\text { flavoured water, chocolate milk, } \\
\text { citrus juices, cranberry juice, } \\
\text { herb tea blends, green teas, } \\
\text { most fruit juices, regular coffee, } \\
\text { sodas, soy milk, tea, } \\
\text { energy drinks, powdered drinks }\end{array}$ \\
\hline Grain products & $\begin{array}{l}\text { Buckwheat, cornbread, white bread, } \\
\text { oat bread, pita, potato bread, } \\
\text { couscous, matzo, millet, oatmeal, } \\
\text { pasta, rice, quinoa, rice, } \\
\text { spelt, most cereals }\end{array}$ & $\begin{array}{l}\text { Amaranth, grits, rye bread, sourdough bread, } \\
\text { some graham crackers without problem ingredients, } \\
\text { whole wheat bread, instant hot cereals }\end{array}$ & $\begin{array}{l}\text { Breads or cereals with preservatives, } \\
\text { soy flour, prepared pasta or } \\
\text { rice dishes }\end{array}$ \\
\hline Fats and nuts & $\begin{array}{l}\text { Peanuts, butter, canola oil, } \\
\text { coconut w/o preservatives, } \\
\text { coconut oil, corn oil, margarine, } \\
\text { olive oil, peanut oil, } \\
\text { safflower oil, sesame oil, } \\
\text { shortening, soy oil, } \\
\text { homemade salad dressings }\end{array}$ & $\begin{array}{l}\text { Almonds, almond butter, cashews, tahini, } \\
\text { sunflower seeds, butter-flavoured shortening }\end{array}$ & $\begin{array}{l}\text { Filberts, hazelnuts, macadamia nuts, } \\
\text { mayonnaise, most prepared salad } \\
\text { dressings, peanuts, pecans, } \\
\text { pistachio nuts, English and black } \\
\text { walnuts }\end{array}$ \\
\hline Soups & $\begin{array}{l}\text { Homemade soups with } \\
\text { non-problem meats } \\
\text { (see below) and vegetables }\end{array}$ & $\begin{array}{l}\text { Canned, low sodium, organic soups without } \\
\text { problem ingredients }\end{array}$ & $\begin{array}{l}\text { Bouillon cubes, bouillon powder, } \\
\text { most packaged and canned soups }\end{array}$ \\
\hline $\begin{array}{l}\text { Meat, fish } \\
\text { and poultry }\end{array}$ & $\begin{array}{l}\text { Beef, chicken, eggs, fish, lamb, liver } \\
\text { (beef or chicken), pork, } \\
\text { shellfish, fresh crabmeat, shrimp, } \\
\text { turkey, veal, whey protein powder }\end{array}$ & $\begin{array}{l}\text { Anchovies, bacon, Canadian bacon, caviar, } \\
\text { corned beef, liverwurst, prosciutto, some } \\
\text { sausages without problem ingredients, } \\
\text { ham, soy-free veggie burgers }\end{array}$ & $\begin{array}{l}\text { Bologna, hot dogs, most sausage, } \\
\text { pepperoni, salami, smoked fish, } \\
\text { canned crabmeat, soy products }\end{array}$ \\
\hline $\begin{array}{l}\text { Cheeses and } \\
\text { other dairy }\end{array}$ & $\begin{array}{l}\text { Cream cheese, cottage cheese, } \\
\text { feta, mozzarella, ricotta, } \\
\text { string cheeses, American } \\
\text { cheese, whipped cream, } \\
\text { ice cream, milk, Lactaid, rice milk }\end{array}$ & $\begin{array}{l}\text { Buttermilk, canned parmesan cheese, Monterey jack, } \\
\text { Cool Whip, some sherbets, } \\
\text { some frozen yogurt, Rice Dream }\end{array}$ & $\begin{array}{l}\text { Aged cheeses, blue cheese, brie, } \\
\text { brick parmesan, camembert, } \\
\text { cheddar, edam, emmentaler, } \\
\text { gruyere, hard jack, roquefort, } \\
\text { sorbet, soy milk, soy cheese, } \\
\text { Sour cream, stilton, swiss, } \\
\text { Cheez Wiz, yogurt }\end{array}$ \\
\hline Fruits & $\begin{array}{l}\text { Dates without preservatives, coconut } \\
\text { without preservatives, pears, } \\
\text { apples, homemade applesauce, } \\
\text { watermelon }\end{array}$ & $\begin{array}{l}\text { Bananas, brown raisins, cherimoya, citrus peels, } \\
\text { crenshaw melon, dried currants, Gala apples, } \\
\text { honeydew, mango, maraschino cherries, rhubarb }\end{array}$ & $\begin{array}{l}\text { Apricots, all citrus fruit, cantaloupe, } \\
\text { cherries, dried fruit peaches, } \\
\text { most plums, most dried figs, } \\
\text { golden raisins, grapes, guava, } \\
\text { kiwi fruit, most berries, } \\
\text { passion fruit, papaya, persimmon, } \\
\text { pineapple, starfruit }\end{array}$ \\
\hline Snacks & $\begin{array}{l}\text { Almonds, carrots, celery, plain corn chips, } \\
\text { plain potato chips, soda crackers, } \\
\text { oatmeal bars, peanuts, popcorn, pretzels }\end{array}$ & $\begin{array}{l}\text { Glazed doughnuts, graham crackers, fruit and } \\
\text { nut bars with OK ingredients, licorice, } \\
\text { pizza with OK ingredients }\end{array}$ & $\begin{array}{l}\text { Seasoned potato chips, processed } \\
\text { baked goods, dessert } \\
\text { cakes - fast food restaurants }\end{array}$ \\
\hline
\end{tabular}




\begin{tabular}{|c|c|c|c|}
\hline Food type & Eat & Try it & Avoid \\
\hline $\begin{array}{l}\text { Desserts } \\
\text { and sweets }\end{array}$ & $\begin{array}{l}\text { Brown sugar, carob, carrot muffins or cake, } \\
\text { creme brulee, custards, divinity, } \\
\text { homemade pound cake, } \\
\text { homemade white/yellow cakes, } \\
\text { homemade vanilla frosting, homemade } \\
\text { caramel frosting, honey, } \\
\text { licorice, maple syrup, pear pastries, } \\
\text { sugar, sugar cookies, tapioca, } \\
\text { vanilla ice cream, vanilla pudding }\end{array}$ & $\begin{array}{l}\text { Banana bread, blueberry pastries, caramel candies, } \\
\text { peppermint ice cream, plain pastries with almonds, } \\
\text { plain cheesecakes, some frozen yogurt, some hard } \\
\text { candies without acids, some popsicles, } \\
\text { Splenda }{ }^{\circledR} \text { (sucralose), stevia, white chocolate }\end{array}$ & $\begin{array}{l}\text { Acesulfame } \mathrm{K} \text {, aspartame, catsup, } \\
\text { milk chocolate, dark chocolate, } \\
\text { coffee ice cream, desserts with } \\
\text { problem nuts, mustard, pastries } \\
\text { with problem fruits, pecan pie, } \\
\text { sorbets, store-bought fruitcakes, } \\
\text { mincemeat pie, Nutrasweet }{ }^{\circledR}, \\
\text { saccharine }\end{array}$ \\
\hline $\begin{array}{l}\text { Seasonings } \\
\text { and additives }\end{array}$ & $\begin{array}{l}\text { Allspice, almond extract, anise, basil, } \\
\text { caraway seed, coriander, dill, fennel, garlic, } \\
\text { mace, marjoram, oregano, poppy seed, } \\
\text { rosemary, sage, salt, thyme, } \\
\text { tarragon, vanilla extract }\end{array}$ & $\begin{array}{l}\text { Black pepper, celery seed, cilantro, cinnamon, cumin } \\
\text { (small amount), dried parsley, dried chervil, ginger, } \\
\text { lemon extract, malt powder, nutmeg, onion powder, } \\
\text { orange extract, turmeric }\end{array}$ & $\begin{array}{l}\text { Ascorbic acid, autolyzed yeast, } \\
\text { butylated hydroxyanisole (BHA) } \\
\text { and butylated hydroxytoluene (BHT), } \\
\text { benzoates, caffeine, cayenne, cloves, } \\
\text { chilli powder, citric acid, hot curry } \\
\text { powder, hydrolyzed protein, meat } \\
\text { tenderizers, miso, oleoresin paprika, } \\
\text { paprika, red pepper, soy sauce, } \\
\text { tamari, vinegar, Worcestershire } \\
\text { sauce, MSG (monosodium, } \\
\text { glutamate), metabisulphites, sulphites }\end{array}$ \\
\hline Fibre supplements & Acacia fibre, Benefiber, plain Metamucil & Colace, Metamucil cinnamon wafers & $\begin{array}{l}\text { Metamucil orange, Metamucil berry } \\
\text { burst, sugar-free psyllium fibre, senna }\end{array}$ \\
\hline
\end{tabular}

Adapted from IC/PBS Ad Hoc Committee on Diet. 2009 IC/PBS Food List: Bladder \& Prostate Friendly Foods; and Understanding Diet and IC. Available at: http:// www.ic-network.com/handbook/diet.html. Accessed 12 January 2012.

the symptoms of BPS/IC (urinary urgency and/or frequency, pressure and pain; Table 1) (34-36). A study in women aged $\geq 40$ years demonstrated that carbonated beverages increased the 1-year incidence of overactive bladder and stress UI (25). There are a number of ingredients that might account for this effect (37). For example, diet sodas contain four well-known bladder irritants: acidic carbonation, citric and other acids, caffeine and artificial sweeteners (29).

Certain foods may stimulate and sensitise nerves in the bladder, which can exacerbate the already heightened nerve sensitivity present in individuals with BPS/IC. Other foods are high in histamine, an irritating substance that can provoke mast cells, which are increased and activated in certain patients with BPS/IC $(29,38)$. A study investigating the possible association between dietary factors and the onset of stress UI in women aged $\geq 40$ years demonstrated that total fat, saturated fatty acids and monounsaturated fatty acids were associated with an increased risk of stress UI (39). Another study reported that a diet low in fat and red meat and high in protein and vegetables may reduce risk of symptomatic benign prostatic enlargement (33).

Guidance is available for the elimination or modification in foods, beverages, food ingredients and nutrients that have been identified as risk factors for bladder conditions, but there may be considerable variability between individuals (34). A Painful Bladder Syndrome/Interstitial Cystitis Ad Hoc Committee on Diet published a list of 'bladder- and prostatefriendly foods' with the intention of helping patients modify their diets to improve bladder health. Eating and drinking 'bladder-friendly' foods and beverages and/or limiting the consumption of foods or beverages known to irritate the bladder to moderate levels can help prevent bladder irritation (37).

\section{Cancer risk factors}

Certain foods/nutrients and beverages, including alcohol, may increase the risk of bladder cancer, whereas other foods may decrease the risk (40-43). A population-based study investigating the effect of dietary micronutrients on the risk of bladder cancer demonstrated that calcium intake was associated with higher risk (41). Additional analysis of this population revealed a possible association between bladder cancer and a high intake of cheese, while noting a protective effect for olive oil (42).

\section{Vitamin D}

There is now a body of literature supporting the protective role of vitamin $\mathrm{D}$ in maintaining continence 
in women and men. Three large epidemiologic studies have provided evidence linking UI risk with insufficient vitamin D levels (44-46). One study investigated the association between nutrient composition of the diet and the onset of overactive bladder and UI in community-dwelling women $\geq 40$ years of age (44). After a year, higher vitamin D intake was significantly associated with a decreased risk of the onset of overactive bladder and UI in women. Another study characterised the prevalence of vitamin D deficiency in non-pregnant women with pelvic floor disorders in the National Health and Nutrition Examination Survey (NHANES) (45). Multivariable analysis revealed that the likelihood of UI was significantly reduced by $45 \%$ when vitamin D levels were normal. In the third study, NHANES data showed that men with deficient vitamin D levels had a significantly higher rate of moderate/severe UI and a greater likelihood of having $\geq 1$ LUTS, including nocturia, incomplete emptying, hesitancy and UI (46). Because vitamin D receptors exist in many tissues and organ systems, it is possible that vitamin D may help prevent UI and other bladder symptoms by increasing pelvic floor muscle strength, improving urethral sphincter function, inhibiting detrusor muscle overactivity and/or decreasing prostatic hypertrophy.

\section{Cranberry products}

Diet can also play a role in the development of UTIs, particularly in women for whom UTIs are the most common infection. Cranberries, cranberry juice and cranberry supplements have been shown to have a protective or preventative effect against UTI, particularly recurrent UTIs in women $(47,48)$. A-type proanthocyanidins, which are a component of cranberries, inhibit bacterial adherence to the uroepithelium in a dose-dependent manner $(49,50)$. Despite this, there is conflicting evidence and not all studies have been supportive.

In a study comparing the antibiotic trimethoprimsulfamethoxazole (TMP-SMX) with cranberry supplements in 221 premenopausal women with recurrent UTIs, participants in the TMP-SMX group had fewer symptomatic UTIs over 12 months than those in the cranberry supplement group; however, antibiotic resistance increased in the TMP-SMX group and not in the cranberry group (51). Another study evaluated the effect of drinking 8 ounces of cranberry juice twice daily on the risk of recurring UTI among 319 college women with an acute UTI; those drinking cranberry juice did not have a decreased 6-month incidence of a second UTI compared with placebo (52). Even with conflicting evidence, incorporating the recommendation of cranberry intake as a protective measure in community-based interventions, such as sexual health interventions or healthy ageing interventions, may help reduce the risk for UTIs among highly susceptible populations.

\section{Drug abuse}

Severe LUTS, including urgency, UI, frequency and nocturia, as well as cystitis, haematuria, reduced bladder capacity, hydronephrosis and renal impairment have been associated with ketamine abuse (53). The mechanism(s) producing these effects on the bladder is unknown. Symptoms appear to improve after cessation of ketamine in cases where irreversible damage to the renal tract has not occurred (53).

\section{Body-mass index}

Related to dietary intake is the ability to maintain a healthy weight. Obesity is an established risk factor for UI, as demonstrated in several population-based studies $(14,54)$. In addition, several weight loss intervention studies have demonstrated that weight loss is associated with reductions in UI (55-57). The most definitive randomised clinical trial showed that overweight and obese women who participated in a 6month behavioural weight loss intervention (resulting in an $8 \%$ weight loss) reduced UI episodes by $47 \%$ (compared with $28 \%$ in the control group) and reduced urgency UI episodes by $42 \%$ (compared with $26 \%$ in control) (57). Elevated body-mass index also appears to be associated with increased incidence of nocturia and increased risk for UTI (58-60). In men, obesity is associated with benign prostatic enlargement and increased risk of LUTS $(61,62)$. Given the benefits of weight loss for urinary symptoms, it might be prudent to integrate this information into weight loss programmes to provide an added incentive for overweight men and women to engage in the longterm behaviour changes needed to lose weight.

\section{Fluid intake volume}

Fluid intake volume is also an important factor affecting bladder function, as consuming a healthy amount of fluid can help prevent UI and other bladder conditions (16,63-66). Limiting fluid intake is sometimes used as a self-directed 'preventative' strategy by those experiencing urgency, frequency, nocturia or UI $(3,63,64,67)$. However, this practice can increase urine concentration, leading to irritation of the bladder mucosa, thereby increasing the incidence of LUTS and UTI $(68,69)$.

Conversely, excessive fluid intake may exacerbate urinary symptoms. Fluid intake averaging $>3700 \mathrm{ml} /$ day has been associated with a higher voiding frequency and incidence of UI compared with an intake of approximately $2400 \mathrm{ml} /$ day (70). A 
study of 30 healthy men aged 21-32 years demonstrated that participants in the excessive fluid intake group not only had significantly increased urine volume and frequency but also had significantly higher bladder pressure compared with those in the normal fluid intake group (71). Excessive evening fluid intake in particular may predispose individuals to nocturia, especially older adults and other individuals who experience nocturnal polyuria as a result of sleep apnoea, heart failure or other medical conditions affecting urine production $(16,66)$.

Overall, promoting healthy fluid intake (approximately $25-30 \mathrm{ml} / \mathrm{kg} /$ day) may dilute the urine, balance the $\mathrm{pH}$ of urine, reduce bladder irritation and help prevent UTIs $(16,63,65,66)$. In addition, healthy fluid intake (especially water) may reduce risk of bladder cancer $(65,72)$.

\section{Voiding habits and technique}

\section{Voiding frequency}

Voiding frequency can be driven by many factors, including bladder sensation, convenience, opportunity, health beliefs and fear of UI episodes. Excessive frequency of voiding is often adopted as a strategy to avoid urgency and UI episodes (73). However, it is thought that frequent voiding, over time, leads to reduced functional bladder capacity and bladder dysfunction (74). Conversely, infrequent voiding may irritate the bladder mucosa, increasing the incidence of LUTS and UTI $(68,69)$. It is also possible that infrequent voiding may overdistend the bladder, leading to reduced the awareness of bladder sensation, and contribute to UTI (75).

\section{Postcoital voiding}

Sexual intercourse has been positively correlated with UTIs. Proper hygiene, particularly postcoital hygiene for women, including emptying the bladder following sexual intercourse, has been recommended for the prevention of UTIs (76). Public health sexual education programmes should incorporate these concepts to inform individuals of the importance of bladder health to highlight that the occurrence of UTI in this context can be circumvented.

\section{Voiding technique}

Without an understanding of normal bladder function, people may develop the habit of voiding by valsalva (bearing down) or fail to relax the pelvic floor. Some women in particular report hovering over public toilet seats to avoid contact with unclean surfaces, which makes it difficult to relax and empty the bladder $(77,78)$. Improper voiding techniques can lead to dysfunctional voiding and incomplete emptying, which may increase voiding frequency and risk of UTI (79).

Healthy toileting behaviours include a relaxed position for urination, relaxation of the pelvic floor and allowing adequate time for the bladder to empty (77,78,80-84). Public education, including messages for children and young adults, to disseminate a clear understanding of how the bladder fills and empties, normal voiding habits and problems associated with poor habits has potential to promote bladder health on a population level.

\section{Bowel habits and constipation}

Bowel health is known to affect bladder function, especially in older adults. Specifically, faecal impaction and constipation are associated with LUTS, including OAB symptoms of urgency, urgency UI, frequency and nocturia, as well as incomplete emptying $(85,86)$. Furthermore, treatment of constipation has been shown to improve LUTS in children and adults (87-89).

\section{Physical activity and exercise}

The duration and level of competition have been correlated with LUTS across several sports, with high impact sports more frequently associated with UI than low impact sports (90). High impact sports appear to be associated with functional and anatomical changes in pelvic floor muscles. For female athletes who endure high impact, frequent intense training in landing/jumping sports (e.g. gymnastics, basketball), increased size and altered function of pelvic floor muscles have been demonstrated compared with athletes who participated in non-landing/ jumping sports (e.g. swimming, walking) (91).

On the other hand, long-term, moderate physical activity has been shown to be inversely related to UI (92), and lower activity levels have been associated with 2-3 times greater likelihood of incident LUTS in women (20). Furthermore, most studies in men indicate that physical activity decreases the risk of benign prostatic enlargement, suggesting that physical activity may be beneficial in men with LUTS (61). Thus, public health programmes addressing inactivity levels or promoting exercise programmes could incorporate the potential benefit of physical activity to bladder health as an added incentive.

\section{Pelvic floor muscle skills and exercise}

Healthy pelvic floor muscle function is an important factor for the maintenance of overall bladder health. Keeping muscles strong maintains tone, supports pelvic organs and promotes active use of pelvic floor muscles to control the bladder outlet.

Pelvic floor muscle training is a well-established treatment for stress UI in women, as well as men 
$(93,94)$. Behavioural training, which combines pelvic floor muscle training with urge suppression strategies, has proven effective for reducing urgency, frequency, nocturia and urgency UI in women and in men $(3,74)$. Given the efficacy of these behavioural approaches to treating bladder symptoms, their low side effect profile and safety, they have also been examined as preventive interventions in high-risk populations, including child-bearing women, older women and men undergoing radical prostatectomy $(95,96)$.

A systematic review comparing antenatal and postnatal care including pelvic floor muscle training with standard care demonstrated that pelvic floor muscle training may prevent UI in late pregnancy and postpartum and may effectively reduce persistent UI thereafter (97). Thus, public health initiatives aimed at improving the overall health of pregnant women should include education on executing pelvic floor muscle exercises to prevent or reverse compromised pelvic floor muscle function.

Although age is an established risk factor for UI, there is a single randomised clinical trial demonstrating the value of pelvic floor muscle training in a behaviour modification programme for reducing 12 month incidence of UI and 24-h, daytime and nocturnal voiding frequency in continent older women (98).

Because UI is often predictable after radical prostatectomy, behavioural interventions have also been implemented in the early postoperative period to help reduce symptom duration and severity $(99,100)$. Another approach is to teach pelvic floor muscle control preoperatively, so that patients can practise their muscle skills before surgery and be more prepared to exercise and use their pelvic floor muscles immediately after catheter removal (96). There are now several randomised controlled clinical trials of peri-operative pelvic floor muscle training programmes that have shown reduced duration and severity of UI after prostatectomy $(96,99,100)$.

Given the preventive value of safe behavioural intervention within at-risk populations, and our relative inability to predict who will develop bladder conditions, it is reasonable to consider the potential value of these interventions for preventing bladder symptoms on a broader population scale. Educating women and men about pelvic floor muscle exercises may enable them to consciously maintain better muscle tone and support for pelvic organs including the bladder and urethra. Pelvic floor muscle exercise, which has been used to prevent UI during pregnancy and following delivery, may be employed to prevent or deter pelvic floor weakening associated with ageing or weight gain. Better pelvic floor muscle relaxation may help people to void more naturally and effectively, and prevent problems with dysfunctional voiding. Educating individuals about how to contract their pelvic floor muscles to brace during coughing, sneezing and heavy lifting may help preserve the pelvic floor and prevent some of the anatomical changes that lead to stress UI and pelvic organ prolapse (101). Similarly, learning how to respond to urgency by staying still and using urge suppression strategies, rather than rushing to the bathroom, may enable people to control their voiding patterns, rather than lose control of urgency and voiding frequency.

\section{Conclusions}

This review has focused on behavioural and lifestyle factors that affect bladder health, explored associated risk for bladder conditions, and discussed modifications of these factors that contribute to maintenance or improvement of bladder health. Many of the behavioural modifications discussed can be employed to improve bladder health or to prevent or reduce the deterioration of bladder health. There are several key behavioural and lifestyle modifications that may be beneficial to incorporate into new or existing interventions to further improve the health of a population.

- 'Understand your bladder.' The more general knowledge you acquire and assimilate into your lifestyle, the more likely you are to prevent bladder health problems.

- Do not smoke.

- Consume a healthy amount of fluid (25-30 ml/kg/ day, the amount needed to empty the bladder every 3-4 h).

- Eliminate or consume known bladder irritants in moderation.

- Adopt healthy toileting behaviours.

- Practice pelvic floor muscle exercises and preemptive pelvic floor contraction.

- Practice postcoital hygiene (women).

- Avoid constipation and obesity.

Although clinical practice may be assumed to be the most appropriate ground for this education, there is a need to disseminate the 'bladder basics' more broadly and educate at-risk populations, as well as the general public. It is crucial to extend these messages into the general population using broader public health interventions to reach those who have not yet developed bladder conditions and to maximise the prevention impact of these behaviour changes.

\section{Acknowledgements}

Funding for two expert panel meetings on bladder health, at which this manuscript was conceptualised, was provided by Pfizer Inc. Editorial assistance was 
provided by Nicole Lodowski of Pfizer Inc and Colin P. Mitchell, PhD, of Complete Healthcare Communications, Inc. and was funded by Pfizer Inc.

\section{Disclosures}

KLB is a consultant for Pfizer. DKN is on the Advisory Board of Ferring, Merck and Astellas. MTR is a consultant and speaker for Astellas, Horizon and Pfizer, a consultant for Ferring and Lilly, and a speaker for Forest and Ortho-McNeil. CS is a consultant for Pfizer.

$$
\begin{array}{r}
\text { K. L. Burgio, }{ }^{1,2} \text { D. K. Newman, }{ }^{3} \\
\text { M. T. Rosenberg, }{ }^{4} \text { C. Sampselle } \\
\end{array}
$$

${ }^{2}$ Department of Medicine, University of Alabama at Birmingham, Birmingham, AL, USA

${ }^{3}$ Division of Urology, University of Pennsylvania Perelman School of Medicine, Philadelphia, PA, USA ${ }^{4}$ Mid-Michigan Health Centers, Jackson, MI, USA ${ }^{5}$ Division of Health Promotion and Risk Reduction, University of Michigan School of Nursing, Ann Arbor, MI, USA

Correspondence to: Kathryn L. Burgio, Geriatric Research, Education and Clinical Center Birmingham VA Medical Center 700 South 19th Street Birmingham, AL 35233, USA Tel.: +1 2059343259 Fax: +1 2055587068 Email: kburgio@uabmc.edu

\section{References}

1 Feenstra TL, van Baal PM, Jacobs-van der Bruggen $\mathrm{MO}$ et al.Targeted versus universal prevention. A resource allocation model to prioritize cardiovascular prevention. Cost Eff Resour Alloc 2011; 9: 14.

2 Church T. Exercise in obesity, metabolic syndrome, and diabetes. Prog Cardiovasc Dis 2011; 53: 412-8.

3 Wyman JF, Burgio KL, Newman DK. Practical aspects of lifestyle modifications and behavioural interventions in the treatment of overactive bladder and urgency urinary incontinence. Int $\mathrm{J}$ Clin Pract 2009; 63: 1177-91.

4 Hines SH, Seng JS, Messer KL, et al. Adherence to a behavioral program to prevent incontinence. West J Nurs Res 2007; 29: 36-56. discussion 7-64.

5 American Cancer Society. Risk Factors for Bladder Cancer. 2011. http://www.cancer.org/Cancer/BladderCancer/OverviewGuide/bladder-cancer-overview-risk-factors. (accessed November 2011).

6 Brownson RC, Chang JC, Davis JR. Occupation, smoking, and alcohol in the epidemiology of bladder cancer. Am J Public Health 1987; 77: 1298-300.

7 Baris D, Karagas MR, Verrill C, et al. A case-control study of smoking and bladder cancer risk: emergent patterns over time. J Natl Cancer Inst 2009; 101: 1553-61.

8 Castelao JE, Yuan JM, Skipper PL et al. Genderand smoking-related bladder cancer risk. J Natl Cancer Inst 2001; 93: 538-45.

9 Johansson SL, Cohen SM. Epidemiology and etiology of bladder cancer. Semin Surg Oncol 1997; 13: 291-8.

10 Hartge P, Silverman D, Hoover R et al. Changing cigarette habits and bladder cancer risk: a casecontrol study. J Natl Cancer Inst 1987; 78: 111925.

11 Vilensky D, Lawrentschuk N, Hersey K, Fleshner NE. A smoking cessation program as a resource for bladder cancer patients. Can Urol Assoc J 2011; 6: E167-73.

12 Strope SA, Montie JE. The causal role of cigarette smoking in bladder cancer initiation and progres- sion, and the role of urologists in smoking cessation. J Urol 2008; 180: 31-7. discussion 7.

13 Bump RC, McClish DK. Cigarette smoking and urinary incontinence in women. Am J Obstet Gynecol 1992; 167: 1213-8.

14 Hannestad YS, Rortveit G, Daltveit AK, Hunskaar S. Are smoking and other lifestyle factors associated with female urinary incontinence? The Norwegian EPINCONT Study. BJOG 2003; 110: 247-54.

15 Bump RC, McClish DM. Cigarette smoking and pure genuine stress incontinence of urine: a comparison of risk factors and determinants between smokers and nonsmokers. Am J Obstet Gynecol 1994; 170: 579-82.

16 Newman DK. Lifestyle interventions. In: Bourcier AP, McGuire EJ, Abrams P, eds. Pelvic Floor Disorders. Philadelphia: Elsevier Saudners, 2004: 269-76.

17 Koskimaki J, Hakama M, Huhtala H, Tammela TL. Association of smoking with lower urinary tract symptoms. J Urol 1998; 159: 1580-2.

18 Bing MH, Moller LA, Jennum $\mathrm{P}$ et al. Nocturia and associated morbidity in a Danish population of men and women aged 60-80 years. BJU Int 2008; 102: 808-14. discussion 14-5.

19 Tahtinen RM, Auvinen A, Cartwright $\mathrm{R}$ et al. Smoking and bladder symptoms in women. Obstet Gynecol 2011; 118: 643-8.

20 Maserejian NN, Kupelian V, Miyasato G et al. Are physical activity, smoking and alcohol consumption associated with lower urinary tract symptoms in men or women? Results from a population based observational study. J Urol 2012; 188: 490-5.

21 Brubaker L, Fanning K, Goldberg EL et al. Predictors of discontinuing overactive bladder medications. BJU Int 2010; 105: 1283-90.

22 Kennedy CM, Bradley CS, Galask RP, Nygaard IE. Risk factors for painful bladder syndrome in women seeking gynecologic care. Int Urogynecol $J$ Pelvic Floor Dysfunct 2006; 17: 73-8.

23 Platz EA, Rimm EB, Kawachi I et al. Alcohol consumption, cigarette smoking, and risk of benign prostatic hyperplasia. Am J Epidemiol 1999; 149: 106-15.

24 Haidinger G, Madersbacher S, Waldhoer T et al. The prevalence of lower urinary tract symptoms in Austrian males and associations with sociodemographic variables. Eur J Epidemiol 1999; 15: 717-22.

25 Dallosso HM, McGrother CW, Matthews RJ, Donaldson MM. The association of diet and other lifestyle factors with overactive bladder and stress incontinence: a longitudinal study in women. BJU Int 2003; 92: 69-77.

26 Dallosso HM, Matthews RJ, McGrother CW et al. The association of diet and other lifestyle factors with the onset of overactive bladder: a longitudinal study in men. Public Health Nutr 2004; 7: 885-91.

27 Jura YH, Townsend MK, Curhan GC et al. Caffeine intake, and the risk of stress, urgency and mixed urinary incontinence. $J$ Urol 2011; 185: 1775-80.

28 Lohsiriwat S, Hirunsai M, Chaiyaprasithi B. Effect of caffeine on bladder function in patients with overactive bladder symptoms. Urol Ann 2011; 3: 14-8.

29 Interstitial Cystitis Network. http://www.ic-network.com/handbook/diet.html (January 12 2012).

30 Haidinger G, Temml C, Schatzl G et al. Risk factors for lower urinary tract symptoms in elderly men. For the Prostate Study Group of the Austrian Society of Urology. Eur Urol 2000; 37: 413-20.

31 Seim A, Hoyo C, Ostbye T, Vatten L. The prevalence and correlates of urinary tract symptoms in Norwegian men: the HUNT study. BJU Int 2005; 96: 88-92.

32 Parsons JK, Im R. Alcohol consumption is associated with a decreased risk of benign prostatic hyperplasia. J Urol 2009; 182: 1463-8.

33 Kristal AR, Arnold KB, Schenk JM et al. Dietary patterns, supplement use, and the risk of symptomatic benign prostatic hyperplasia: results from the prostate cancer prevention trial. Am J Epidemiol 2008; 167: 925-34.

34 Shorter B, Lesser M, Moldwin RM, Kushner L. Effect of comestibles on symptoms of interstitial cystitis. J Urol 2007; 178: 145-52.

35 Tettamanti G, Nyman-Iliadou A, Pedersen NL et al. Influence of smoking, coffee, and tea consumption on bladder pain syndrome in female twins. Urology 2011; 77: 1313-7. 
36 Hanno P, Lin A, Nordling J et al. Bladder Pain Syndrome Committee of the International Consultation on Incontinence. Neurourol Urodyn 2010; 29: 191-8.

37 IC/PBS Ad Hoc Committee on Diet. 2009. IC/PBS food list: bladder and prostate friendly foods. 2009.

38 Friedlander JI, Shorter B, Moldwin RM. Diet and its role in interstitial cystitis/bladder pain syndrome (IC/BPS) and comorbid conditions. BJU Int 2012; 109: 1584-91.

39 Dallosso H, Matthews R, McGrother C, Donaldson M. Diet as a risk factor for the development of stress urinary incontinence: a longitudinal study in women. Eur J Clin Nutr 2004; 58: $920-6$.

40 Zeegers MP, Kellen E, Buntinx F, van den Brandt PA. The association between smoking, beverage consumption, diet and bladder cancer: a systematic literature review. World J Urol 2004; 21 : 392-401.

41 Brinkman MT, Buntinx F, Kellen E et al. Dietary intake of micronutrients and the risk of developing bladder cancer: results from the Belgian casecontrol study on bladder cancer risk. Cancer Causes Control 2011; 22: 469-78.

42 Brinkman MT, Buntinx F, Kellen E et al. Consumption of animal products, olive oil and dietary fat and results from the Belgian case-control study on bladder cancer risk. Eur J Cancer 2011; 47 436-42.

43 Kellen E, Zeegers M, Paulussen A et al. Fruit consumption reduces the effect of smoking on bladder cancer risk. The Belgian case control study on bladder cancer. Int J Cancer 2006; 118: 2572-8.

44 Dallosso HM, McGrother CW, Matthews RJ, Donaldson MM. Nutrient composition of the diet and the development of overactive bladder: a longitudinal study in women. Neurourol Urodyn 2004; 23: 204-10

45 Badalian SS, Rosenbaum PF. Vitamin D and pelvic floor disorders in women: results from the National Health and Nutrition Examination Survey. Obstet Gynecol 2010; 115: 795-803.

46 Vaughan CP, Johnson TM 2nd, Goode PS et al. Vitamin D and lower urinary tract symptoms among US men: results from the 2005-2006 National Health and Nutrition Examination Survey. Urology 2011; 78: 1292-7.

47 Jepson RG, Craig JC. Cranberries for preventing urinary tract infections. Cochrane Database Syst Rev 2008; 1: CD001321.

48 Eells SJ, McKinnell JA, Miller LG. Daily cranberry prophylaxis to prevent recurrent urinary tract infections may be beneficial in some populations of women. Clin Infect Dis 2011; 52: 1393-4. author reply 4-5.

49 Liu Y, Pinzon-Arango P, Gallardo-Moreno AM, Camesano TA. Direct adhesion force measurements between E. coli and human uroepithelia cells in cranberry juice cocktail. Mol Nutr Food Res 2010; 54: 1-9.

50 Rossi R, Porta S, Canovi B. Overview on cranberry and urinary tract infections in females. J Clin Gastroenterol 2010; 44 (Suppl. 1): S61-2.

51 Beerepoot MA, ter Riet G, Nys S et al. Cranberries vs antibiotics to prevent urinary tract infections: a randomized double-blind noninferiority trial in premenopausal women. Arch Intern Med 2011; 171: 1270-8.

52 Barbosa-Cesnik C, Brown MB, Buxton $\mathrm{M}$ et al. Cranberry juice fails to prevent recurrent urinary tract infection: results from a randomized placebocontrolled trial. Clin Infect Dis 2011; 52: 23-30.

53 Middela S, Pearce I. Ketamine-induced vesicopathy: a literature review. Int J Clin Pract 2011; 65: 27-30.

54 Coyne KS, Kaplan SA, Chapple CR et al. Risk factors and comorbid conditions associated with lower urinary tract symptoms: EpiLUTS. BJU Int 2009; 103 (Suppl. 3): 24-32.

55 Wing RR, West DS, Grady D et al. Effect of weight loss on urinary incontinence in overweight and obese women: results at 12 and 18 months. Urol 2010; 184: 1005-10

56 Subak LL, Whitcomb E, Shen $\mathrm{H}$ et al. Weigh loss: a novel and effective treatment for urinary incontinence. J Urol 2005; 174: 190-5.

57 Subak LL, Wing R, West DS et al. Weight loss to treat urinary incontinence in overweight and obese women. N Engl J Med 2009; 360: 481-90.

58 Tikkinen KA, Auvinen A, Huhtala H, Tammela TL. Nocturia and obesity: a population-based study in Finland. Am J Epidemiol 2006; 163: 1003-11.

59 Semins MJ, Shore AD, Makary MA et al. The impact of obesity on urinary tract infection risk. Urology 2012; 79: 266-9.

60 Tikkinen KA, Auvinen A, Johnson TM 2nd et al A systematic evaluation of factors associated with nocturia - the population-based FINNO study. Am J Epidemiol 2009; 170: 361-8.

61 Parsons JK, Sarma AV, McVary K, Wei JT. Obesity and benign prostatic hyperplasia: clinical connections, emerging etiological paradigms and future directions. J Urol 2009; 182: S27-31.

62 Abdollah F, Briganti A, Suardi N et al. Metabolic syndrome and benign prostatic hyperplasia: evidence of a potential relationship, hypothesized etiology, and prevention. Korean J Urol 2011; 52: 507-16.

63 Swithinbank L, Hashim H, Abrams P. The effect of fluid intake on urinary symptoms in women. J Urol 2005; 174: 187-9.

64 Anders K. Coping strategies for women with urinary incontinence. Baillieres Best Pract Res Clin Obstet Gynaecol 2000; 14: 355-61.

65 Gray M, Krissovich M. Does fluid intake influence the risk for urinary incontinence, urinary tract infection, and bladder cancer? J Wound Ostomy Continence Nurs 2003; 30: 126-31.

66 Griffiths DJ, McCracken PN, Harrison GM Gormley EA. Relationship of fluid intake to voluntary micturition and urinary incontinence in geriatric patients. Neurourol Urodyn 1993; 12: $1-7$

67 Ricci JA, Baggish JS, Hunt TL et al. Coping strategies and health care-seeking behavior in a US national sample of adults with symptoms suggestive of overactive bladder. Clin Ther 2001; 23: 1245-59.

68 Beetz R. Mild dehydration: a risk factor of urinary tract infection? Eur J Clin Nutr 2003; 57 (Suppl. 2): S52-8.

69 Rudaitis S, Pundziene B, Jievaltas M et al. Recurrent urinary tract infection in girls: do urodynamic, behavioral and functional abnormalities play a role? J Nephrol 2009; 22: 766-73.
70 Miller JM, Guo Y, Rodseth SB. Cluster analysis of intake, output, and voiding habits collected from diary data. Nurs Res 2011; 60: 115-23.

71 Schmidt F, Jørgensen TM, Djurhuus JC. Twentyfour-hour ambulatory urodynamics in healthy young men. Scand J Urol Nephrol Suppl 2004; 38: 75-83.

72 Segal S, Saks EK, Arya LA. Self-assessment of fluid intake behavior and the relationship to lower urinary tract symptoms in women with urinary incontinence. I Womens Health (Larchmt) 2011; 20: 1917-21.

73 Anger JT, Nissim HA, Le TX et al. Women's experience with severe overactive bladder symptoms and treatment: insight revealed from patient focus groups. Neurourol Urodyn 2011; 30: 1295-9.

74 Sampselle CM. Teaching women to use a voiding diary. Am J Nurs 2003; 103: 62-4.

75 Lapides J. Mechanisms of urinary tract infection. Urology 1979; 14: 217-25.

76 Hooton TM. Recurrent urinary tract infection in women. Int J Antimicrob Agents 2001; 17: 259 68.

77 Wang K, Palmer MH. Women's toileting behaviour related to urinary elimination: concept analysis. J Adv Nurs 2010; 66: 1874-84.

78 Moore KH, Richmond DH, Sutherst JR et al Crouching over the toilet seat: prevalence among British gynaecological outpatients and its effect upon micturition. Br J Obstet Gynaecol 1991; 98: 569-72.

79 Carlson KV, Rome S, Nitti VW. Dysfunctional voiding in women. J Urol 2001; 165: 143-7. discussion 7-8.

80 Wang K, Palmer MH. Development and validation of an instrument to assess women's toileting behavior related to urinary elimination: preliminary results. Nurs Res 2011; 60: 158-64.

81 Lundblad B, Hellstrom AL, Berg M. Children's experiences of attitudes and rules for going to the toilet in school. Scand J Caring Sci 2010; 24: 219

82 Vythilingum B, Stein DJ, Soifer S. Is "shy bladder syndrome" a subtype of social anxiety disorder? A survey of people with paruresis. Depress Anxiety 2002; 16: 84-7.

83 Soifer S, Himle J, Walsh K. Paruresis (shy bladder syndrome): a cognitive-behavioral treatmen approach. Soc Work Health Care 2010; 49: 494-507.

84 Cai D, You M. An ergonomic approach to public squatting-type toilet design. Appl Ergon 1998; 29 . 147-53.

85 Coyne KS, Cash B, Kopp Z et al. The prevalence of chronic constipation and faecal incontinence among men and women with symptoms of overactive bladder. BJU Int 2011; 107: 254-61.

86 Carter D, Beer-Gabel M. Lower urinary tract symptoms in chronically constipated women. Int Urogynecol J 2012; 23: 1785-89.

87 Loening-Baucke V. Urinary incontinence and urinary tract infection and their resolution with treatment of chronic constipation of childhood. Pediatrics 1997; 100: 228-32.

88 Ouslander JG. Management of overactive bladder. $N$ Engl J Med 2004; 350: 786-99.

89 Charach G, Greenstein A, Rabinovich P et al. Alleviating constipation in the elderly improves lower urinary tract symptoms. Gerontology 2001; 47: $72-6$ 
90 Simeone C, Moroni A, Petteno A et al. Occurrence rates and predictors of lower urinary tract symptoms and incontinence in female athletes. Urologia 2010; 77: 139-46.

91 Kruger JA, Dietz HP, Murphy BA. Pelvic floor function in elite nulliparous athletes. Ultrasound Obstet Gynecol 2007; 30: 81-5.

92 Townsend MK, Danforth KN, Rosner B et al. Physical activity and incident urinary incontinence in middle-aged women. J Urol 2008; 179: 1012-6. discussion 6-7.

93 Dumoulin C, Hay-Smith J. Pelvic floor muscle training versus no treatment, or inactive contro treatments, for urinary incontinence in women. Cochrane Database Syst Rev 2010; 1: CD005654.

94 Burgio KL. Behavioral treatment options for urinary incontinence. Gastroenterology 2004; 126 S82-9.

95 Fine P, Burgio K, Borello-France D et al. Teaching and practicing of pelvic floor muscle exercises in primiparous women during pregnancy and the postpartum period. Am J Obstet Gynecol 2007; 197: 107. e1-5.

96 Centemero A, Rigatti L, Giraudo D et al. Preoperative pelvic floor muscle exercise for early continence after radical prostatectomy: a randomised controlled study. Eur Urol 2010; 57: 1039-43.

97 Hay-Smith J, Morkved S, Fairbrother KA, Herbison GP. Pelvic floor muscle training for prevention and treatment of urinary and faecal incontinence in antenatal and postnatal women. Cochrane Database Syst Rev 2008; 4: CD007471.

98 Diokno AC, Sampselle CM, Herzog AR et al. Prevention of urinary incontinence by behavioral modification program: a randomized, controlled trial among older women in the community. Urol 2004; 171: 1165-71.

99 Ribeiro LH, Prota C, Gomes CM et al. Long-term effect of early postoperative pelvic floor biofeedback on continence in men undergoing radical prostatectomy: a prospective, randomized, controlled trial. J Urol 2010; 184: 1034-9.

100 Manassero F, Traversi C, Ales V et al. Contribution of early intensive prolonged pelvic floor exercises on urinary continence recovery after bladder neck-sparing radical prostatectomy: results of a prospective controlled randomized trial. Neurourol Urodyn 2007; 26: 985-9.

101 Miller JM, Sampselle C, Ashton-Miller J et al. Clarification and confirmation of the Knack maneuver: the effect of volitional pelvic floor muscle contraction to preempt expected stress incontinence. Int Urogynecol J Pelvic Floor Dysfunct 2008; 19: 773-82.

Paper received July 2012, accepted January 2013 